\title{
Pharmacy Students' Knowledge and Attitudes Regarding Cannabis for Medical Purposes
}

\author{
Marina S. Stojanović́ ${ }^{1}$ Ana D. Tomas ${ }^{2}$, Milica M. Paut-Kusturica ${ }^{1}$, \\ Aleksandar L. Rašković ${ }^{1}$, Milan B. Ubaviće ${ }^{2}$ Zdenko S. Tomić1, \\ Ana J. Sabo ${ }^{1}$, Olga J. Horvat ${ }^{1}$ \\ ${ }^{1}$ Department of Pharmacology Toxicology and Clinical Pharmacology, Faculty of Medicine \\ Novi Sad, University of Novi Sad, Novi Sad, Serbia \\ ${ }^{2}$ Institute for Laboratory Diagnostics, Medlab, Novi Sad, Serbia
}

\section{SUMMARY}

Introduction: With the growing trend for legalization of cannabis and its derivatives in Serbia, pharmacists are likely to be consulted on the safety, efficacy, and drug-drug or drug-disease interactions of medical cannabis. Thus, the aim of our study was to assess pharmacy students' knowledge and attitude toward medical cannabis use in Serbia to determine if additional education is needed.

Subjects and methods: In the study students from the final year of the study program of integrated academic studies of pharmacy at the Faculty of Medicine, University of Novi Sad were asked to complete an anonymous questionnaire regarding their knowledge and attitudes on the use of cannabis and its derivatives in medical purposes. After giving their written informed consent, they were instructed by the researchers on how to complete the questionnaire. All questionnaires were administered between August 1, 2017 and August 15, 2017. The study was approved by the Ethical Committee of the Faculty of Medicine in Novi Sad; a total of 80 questionnaires were distributed. The questionnaire consisted of 3 groups of statements on which they should mark level of their agreement related to students' knowledge about the use of cannabis and its derivatives in therapeutical purposes, potential negative effects, dispensing in a pharmacy and legalization of cannabis and its derivatives in medical purposes.

Results: Although $91.2 \%$ of the respondents agreed that cannabis and its derivatives could potentially have therapeutical effects, much lower percentage of respondents (51.3\%) were familiar with possible therapeutical effects of cannabis. The same percentage of respondents learned about therapeutical effects of cannabis from sources other than school. About third (31.3\%) of our respondents thought that the use of cannabis and its derivatives in therapeutical purposes could cause their abuse and the similar percentage of respondents (33.8\%) thought that issuing cannabis and its derivatives in the pharmacy could expose a pharmacist to the certain dangers such as insisting on the issuing without the prescription or robbery. About $90 \%$ of the respondents agreed it is necessary to create clear guidelines for the use of cannabis and its derivatives in therapeutical purposes and $76.3 \%$ of the respondents thought that doctor's prescription is necessary for their dispensing in a pharmacy. Most of the respondents (75\%) agreed that, based on the experiences of the countries which have 
approved the use of cannabis and its derivatives in therapeutical purposes, its use in those purposes should be approved in Serbia.

Conclusion: The majority of pharmacy students supported medical cannabis legalization but only with strict legal regulations and clear guidelines for their use implemented. Further education of the pharmacist about therapeutical effect of cannabis is necessary.

Keywords: cannabis, attitude, legalization, education

\section{INTRODUCTION}

Throughout history, cannabis has been used to treat a variety of diseases and illnesses. In ancient Greece, Rome, China and India, it was used to ameliorate muscle spasms, cramps and pain [1]. At the end of the 19th century in Europe, cannabis was most commonly used for the treatment of pain, asthma, sleep disorders, depression, and loss of appetite [2]. Its medicinal use continued until the first half of the 20th century, when cannabis became subject to legal restrictions due to its psychoactive potential. The possession, use, and sale of cannabis became illegal in most countries of the world [3].

However, there has been a cultural change regarding the perception and use of marijuana medicinally and recreationally over the past 20 years throughout the world. The term "medical marijuana" is generally associated with the use and consumption of the Cannabis plant. Although cannabis contains numerous bioactive constituents, cannabinoids (such as delta-9-tetrahydrocannabinol (THC) - responsible also for marijuana's psychoactive effects and cannabidiol (CBD)) are the most potent components of the plant. Research studies demonstrate some benefits for the use of medical marijuana for conditions such as severe nausea and vomiting, glaucoma, anorexia, chronic pain, and spasticity related to diseases such as multiple sclerosis [4-8].

Smoking marijuana is the main form of consumption of the cannabis in research studies. A dried (cured) cannabis flower can be packed into a pipe, water pipe (bong) or rolling paper ("joint") [9]. Tobacco is often added to assist burning. A few drops of hash oil may be applied to a cigarette or a joint, or the oil may be heated and the vapors inhaled.

Cannabis can also be consumed orally (e.g. desserts, candies, sodas). When swallowed the onset of the psychoactive effects of THC is delayed by about an hour and the 'high' is of lesser intensity although it may last several hours longer [10].

As for the topical application, salves, ointments, lotions, and sprays can be used for the treatment of arthritis, chapped skin, eczema, minor burns, muscle soreness, sunburns, swellings, joint pain, and tendonitis, to name just a few. There are, also, medical cannabis transdermal patches that come in a mild dosages [9].

Nowadays medical cannabis can be prepared also as a sublingual spray [11].

When it comes to Serbia, in the 1700s, Italian farmers and hempseed strains were brought here, making hemp an important crop until the 1900s [12].The first law to sanction drug abuse was the Criminal Code of the Kingdom of Serbs, Croats and Slovenes which entered into force in 1930 [13]. The consumption of the Cannabis plant, which is classified under narcotic drugs in Serbia, meaning it has a high potential for abuse, has no recognized medical uses, and is illegal to prescribe in Serbia (Law on Psychoactive Controlled Substances).

However, the fact that cannabis is the drug most often mentioned in reports of drug law offences in Europe as well as Europe's most commonly used illicit drug has hampered the medicinal use of marijuana. This has prompted patients and physicians to lobby governments to approve its use for medical purposes [14].

In recent years, a number of nations have introduced specific laws and programs to allow patients to use cannabis preparations in various forms to relieve the symptoms of a range of severe, disabling diseases. In Europe, the member states are free to set their own national drug laws, although all of them are parties of the UN Single Convention. For example, the country with longest experience of cannabis use-both medicinal and recreational-is the Netherlands, where physicians have been able to prescribe cannabis preparations for patients for more than 10 years. After 
Netherlands, many countries in Europe have allowed the use of cannabis in medical purposes, Macedonian and Poland are the most recent [15]. In Serbia the use of cannabis and its derivatives in medical purposes is still not legal, but in the recent years there is an increased interest of society in legalization.

With the growing trend in fight for legalization in Serbia, pharmacists are likely to be consulted on the safety, efficacy, and drugdrug or drug-disease interactions of medical cannabis. Also if medical cannabis will be legalized in future, pharmacists will be the ones who will dispense it and answer to patients' questions about its use, benefits or side effects.

Thus, the aim of our study was to assess pharmacy students' knowledge and attitude toward medical marijuana use in Serbia to determine if additional education is needed.

\section{SUBJECTS AND METHODS}

\section{Setting}

Students from the final year of the study program of integrated academic studies of pharmacy at the Faculty of Medicine, University of Novi Sad were asked to complete an anonymous questionnaire regarding their knowledge and attitudes on the use of cannabis and its derivatives in medical purposes. After giving their written informed consent, they were instructed by the researchers on how to complete the questionnaire. All questionnaires were administered between August 1, 2017 and August 15, 2017. The study was approved by the Ethical Committee of the Faculty of Medicine in Novi Sad; a total of 80 questionnaires were distributed.

\section{The questionnaire}

The questionnaire used in this study is based on the questionnaire of Helena Neziri (2015) [16]. Necessary modifications were made to enable correct answers to questions and statements.

After the question about gender, students were given 15 statements about the use of cannabinoids in therapeutical purposes. They were asked to mark one number from one (I completely disagree) to five (I completely agree), according to the level of their agreement with the specific statement. The questionnaire consisted of 3 groups of statements. The first group was related to students' knowledge about the use of cannabis and its derivatives in therapeutical purposes, like their familiarity with the current legalization process, possible therapeutical effects and pharmaceutical forms of cannabis. The second group was related to potential negative effects of using cannabis and its derivatives in therapeutical purposes such as side effects, abuse and other risks. In the third group, students could find the statements about what should or should not be required when it comes to dispensing cannabis in a pharmacy and legalization of cannabis and its derivatives in medical purposes. Through the last statement in this group, students are asked to declare themselves about the issue of legalization specifically in Serbia.

\section{Statement \\ I am familiar with the current legal- ization process of cannabis in thera- peutical purposes in our country.}

Cannabis and its derivatives could potentially have therapeutical effects.

I am familiar with the possible therapeutical effects of cannabis.

I am familiar with pharmaceutical forms of cannabis (pills, oil, tonics, extracts...).

Except from knowledge obtained at school, I learned about therapeutical effects of cannabis from other sources (congresses, seminars, workshops, internet, formal literature)

\begin{tabular}{|c|c|c|c|c|c|c|c|c|c|}
\hline \multicolumn{2}{|c|}{1} & \multicolumn{2}{|c|}{2} & \multicolumn{2}{|c|}{3} & \multicolumn{2}{|c|}{4} & \multicolumn{2}{|c|}{5} \\
\hline $\mathrm{N}$ & $\%$ & $\mathrm{~N}$ & $\%$ & $\mathrm{~N}$ & $\%$ & $\mathrm{~N}$ & $\%$ & $\mathrm{~N}$ & $\%$ \\
\hline
\end{tabular}

$\begin{array}{llllllllll}7 & 8.8 & 28 & 35 & 20 & 25 & 14 & 17.5 & 11 & 13.7\end{array}$

\begin{tabular}{|l|l|l|l|l|l|l|l|l|l|}
\hline 0 & 0 & 0 & 0 & 7 & 8.8 & 40 & 50 & 33 & 41.2 \\
\hline 3 & 3.8 & 22 & 27.5 & 14 & 17.4 & 25 & 31.3 & 16 & 20 \\
\hline 3 & 3.7 & 26 & 32.5 & 20 & 25 & 20 & 25 & 11 & 13.8 \\
\hline
\end{tabular}

$\begin{array}{llllllllll}2 & 2.5 & 20 & 25 & 17 & 21.2 & 28 & 35 & 13 & 16.3\end{array}$

Table 1. Students' knowledge about the use of cannabis and its derivatives in therapetucal purposes

1-Completely disagree; 2-Mostly disagree;

3-Neighter agree nor disagree;

4-Mostly agree;

5-Completely agree 


\section{Data analysis}

Descriptive statistical data analysis was performed with the statistical program Microsoft Excel 2016.

\section{RESULTS}

One third of the respondents $(31.2 \%)$ were familiar with the current legalization process of cannabis in therapeutical purposes in Serbia. Although $91.2 \%$ of the respondents agreed that cannabis and its derivatives could potentially have therapeutical effects, much lower percentage of respondents $(51.3 \%)$ were familiar with possible therapeutical effects of cannabis. About 39\% thought of themselves as familiar with the farmaceutical forms of cannabis such as pills, oil, etc. More than a half of respondents $(51.3 \%)$ learned about therapeutical effects of cannabis from sources other than school.

On the question if the use of cannabis and its derivatives in therapeutical purposes could cause addiction as a side effect the same number of the respondents (31) gave the positive and the negative answer, but more than a half of the respondents (55\%) did not think that the use of cannabis and its derivatives in therapeutical purposes could lead to the consumption of more serious drugs such as heroin or cocaine. About third (31.3\%) of our respondents thought that the use of cannabis and its derivatives in therapeutical purposes could cause their abuse and the similar percentage of respondents $(33.8 \%)$ thought that issuing cannabis and its derivatives in the pharmacy could expose a pharmacist to the certain dangers such as insisting on the issuing without the prescription or robbery.

More than a three quarters (76.3\%) of the respondents thought that doctor's prescription is necessary for dispensing cannabis and its derivatives and $71.3 \%$ thought that cannabis and its derivatives should not be grouped under OTC medications. Little less than 90\% of the respondents agreed it is necessary to create clear guidelines for the use of cannabis and its derivatives in therapeutical purposes, while none of the respondents thought it is not the case. Only one respondent did not think that dispensing cannabis and its derivatives in the pharmacy requires additional education and scientific knowledge of the pharmacist about therapeutical effect of cannabis. Majority of the respondents (86.2\%) thought that the use of cannabis and its derivatives was justified in the case of terminal patients and also, most of the respondents (75\%) agreed that, based on the experiences of the countries which have approved the use of cannabis and its derivatives in therapeutical purposes, its use in those purposes should be approved in Serbia.

\section{DISCUSSION}

In our study $31.2 \%$ of students were familiar with the current legalization process of cannabis in therapeutical purposes in Serbia.

Although almost all the students agreed that cannabis and its derivatives could potentially have therapeutical effects, only half of the respondents $(51.3 \%)$ were famil-
Table 2. Side effect, abuse and dangers related to use of cannabis and its derivatives in medical purposes

1-Completely disagree;

2-Mostly disagree;

3-Neighter agree nor disagree;

4-Mostly agree;

5-Completely agree

\begin{tabular}{|c|c|c|c|c|c|c|c|c|c|c|}
\hline \multirow{2}{*}{ Statement } & \multicolumn{2}{|c|}{1} & \multicolumn{2}{|c|}{2} & \multicolumn{2}{|c|}{3} & \multicolumn{2}{|c|}{4} & \multicolumn{2}{|c|}{5} \\
\hline & $\mathbf{N}$ & $\%$ & $\mathbf{N}$ & $\%$ & $\mathbf{N}$ & $\%$ & $\mathbf{N}$ & $\%$ & $\mathbf{N}$ & $\%$ \\
\hline $\begin{array}{l}\text { One of the worst side effects of us- } \\
\text { ing cannabis and its derivatives in } \\
\text { therapeutical purposes could be ad- } \\
\text { diction. }\end{array}$ & 7 & 8.8 & 24 & 30 & 18 & 22.4 & 19 & 23.8 & 12 & 15 \\
\hline $\begin{array}{l}\text { The use of cannabis and its deriva- } \\
\text { tives, even if it is in therapeutical } \\
\text { purposes, could lead to the more } \\
\text { powerful and dangerous drugs (her- } \\
\text { oin, cocaine...) }\end{array}$ & 20 & 25 & 24 & 30 & 21 & 26.2 & 9 & 11.3 & 6 & 7.5 \\
\hline $\begin{array}{l}\text { The use of cannabis and its deriva- } \\
\text { tives in therapeutical purposes could } \\
\text { cause their abuse. }\end{array}$ & 4 & 5 & 25 & 31.2 & 26 & 32.5 & 13 & 16.3 & 12 & 15 \\
\hline $\begin{array}{l}\text { Dispensing cannabis and its deriva- } \\
\text { tives in the pharmacy could expose } \\
\text { a pharmacist to the certain dangers } \\
\text { (insisting on the issuing without the } \\
\text { prescription, robbery...) }\end{array}$ & 3 & 3.8 & 25 & 31.2 & 25 & 31.2 & 18 & 22.5 & 9 & 11.3 \\
\hline
\end{tabular}




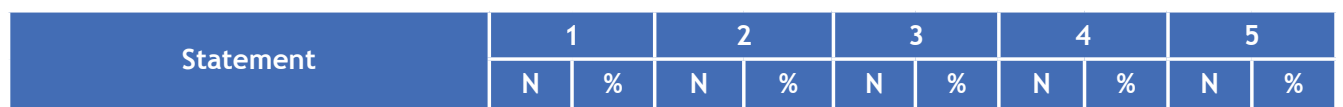

Doctor's recommendation is necessary, specifically doctor's prescripderivatives.

Cannabis and its derivatives need to be grouped under OTC medications.

The use of cannabis and its derivatives in therapeutical purposes demands creation of clear guidelines (indications, pharmaceutical form, dose, longevity of treatment...).

Dispensing cannabis and its derivatives in the pharmacy requires additional education and scientific knowledge of the pharmacist about therapeutical effect of cannabis.

The use of cannabis and its derivatives is justified in the case of terminal patients.

The use of cannabis and its derivatives has been approved in some states in therapeutical purposes. Based on their experiences, the use of cannabis in medical purposes should be approved in Serbia as well.

$\begin{array}{llllllllll}0 & 0 & 1 & 1.3 & 9 & 11.2 & 28 & 35 & 42 & 52.5\end{array}$

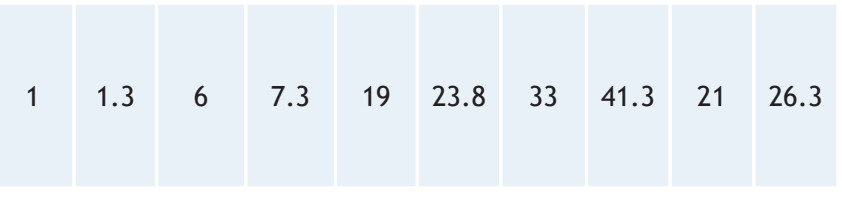
$\begin{array}{llllllllll}0 & 0 & 2 & 2.5 & 9 & 11.2 & 23 & 28.7 & 46 & 57.5\end{array}$ tion for dispensing cannabis and its

\begin{tabular}{|l|l|l|l|l|l|l|l|l|l|}
\hline 1 & 1.3 & 3 & 3.8 & 15 & 18.6 & 26 & 32.5 & 35 & 43.8 \\
\hline 38 & 47.5 & 19 & 23.8 & 14 & 17.4 & 5 & 6.3 & 4 & 5 \\
\hline
\end{tabular}

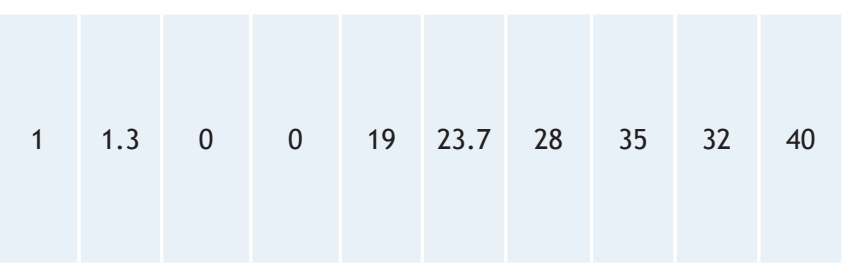

iar with possible therapeutical effects of cannabis which is similar percentage recorded in the study which was carried out among pharmacy students in USA, Kansas, where cannabis is also not legal for medical purposes [17]. Namely, the only approved medical indications correctly identified by more than $50 \%$ of pharmacy students were for the treatment of cancer and glaucoma (91\% and 57\%, respectively). Beside this two, therapeutic uses of medical marijuana are shown in many other diseases and conditions such as spastic disorders, pain, bronchial asthma, nausea and vomiting caused by anticancer drugs, mood disorders, anorexia, epilepsy and glaucoma [18-25].

More than a half $(51.3 \%)$ of the pharmacy students in Novi Sad learned about therapeutical effects of cannabis from sources other than school. In the above mentioned study at the University of Kansas pharmacy students also indicated they had received little to no education regarding the use of medical marijuana in the pharmacy curriculum [17]. This lack of formal education can be reflected in the low confidence and comfort levels in students' ability to answer patients' marijuana questions. What is more, almost every respondent in our study thought that dispensing cannabis and its derivatives in the pharmacy requires additional education and scientific knowledge of the pharmacist about therapeutical effect of cannabis.

One third of the respondents in our study thought that the use of cannabis and its derivatives for therapeutical purposes could cause addiction as a side effect. Dependence is unlikely to present a problem with clinically prescribed doses for patients in therapeutic settings, but withdrawal effects may be undesirable. As well as psychological effects (restlessness, anxiety and insomnia, tremor), there may be a rebound increase in, nausea, diarrhea and other physical symptoms [26]. Withdrawal symptoms are usually short-lived in experimental subjects but they may be more severe in recreational users. When it comes to other side effects, although the acute toxicity of cannabinoids is very low and no deaths have been directly attributable to their recreational or therapeutic use, there are some of the adverse effects commonly observed during the clinical setting. Those include sedation, some psychological effects such as euphoria, dysphoria, anxiety, impaired memory, depersonalization, hallucinations and depression and physical symptoms and signs such as dry mouth, ataxia, blurred vision, tremor, palpitations, tachycardia and hypotension [27].
Table 3. Dispensing in a pharmacy and legalization of cannabis and its derivatives in medical purposes

1-Completely disagree; 2-Mostly disagree;

3-Neighter agree nor disagree; 4-Mostly agree;

5-Completely agree

OTC medications - Over the counter medications 
About third of our respondents thought that the use of cannabis and its derivatives in therapeutical purposes could cause their abuse. The reason for that attitude of those respondents could be the fact that cannabis abuse is increasing and continues to be high in Europe. There are indications that the number of people requiring treatment for cannabis use is increasing. The evidence suggests that more drug users are suffering from cannabis use disorders, and there is growing evidence that cannabis may be becoming more harmful. This is reflected in the high proportion of persons entering treatment for the first time for cannabis use disorders in Europe. Also of note is the important role of international trafficking in cannabis herb cultivation in the region. Serbia, Bulgaria and Romania report that seeds or saplings are often grown in the Netherlands or Belgium and then shipped to South-Eastern Europe for cultivation [28].

Majority of the respondents thought that doctor's prescription is necessary for dispensing cannabis and its derivatives and they should not be grouped under OTC medications. In countries nearby Serbia, where the use of cannabinoids for therapeutical purposes is legal, situation is correlating to our respondents' answers. For example, in Croatia following the recommendation of certain neurology, infectious diseases or cancer specialists, medicines containing THC, dronabinol or nabilone can be prescribed, on non-repeatable prescription, by physicians working in general and family practice, health protection of preschool children and women's healthcare [29]. In Czech Republic currently only 16 specially qualified doctors, such as oncologists and psychologists, are authorized to prescribe cannabis, and only 26 pharmacies can dispense it. No country permits the supply or possession of medical cannabis without a doctor's prescription and the cannabis that is provided for medical use is cultivated under government supervision [30].

Little less than $90 \%$ of the respondents agreed it is necessary to create clear guidelines for the use of cannabis and its derivatives for therapeutical purposes such as indications, pharmaceutical form, dose and longevity of treatment. In Croatia the doctor's prescription should state the amount of THC in a single dose, the number of individual doses, drug form, dosage and method of use. Medicines containing THC can be prescribed in the quantity necessary for treatment up to 30 days. The total amount of prescribed THC in 30 days of treatment must not be greater than 7.5 grams. These medicines may be prescribed to relieve the symptoms of multiple sclerosis, cancer, epilepsy and AIDS. In Czech Republic THC level that can be prescribed is up to $21 \%$. Initially patient limits were 30 grams per month, but these were raised to 180 grams per month in October 2015 [30].

Most of the our respondents (75\%) agreed that, based on the experiences of the countries which have approved the use of cannabis and its derivatives for therapeutical purposes, its use in those purposes should be approved in Serbia as well. Also high percentage of the medical students in Belgrade (63.4) was for medical cannabis legalization according to the study which was carried out among medical students in Belgrade, Serbia [31].The same attitude was among pharmacy students in Kansas where also majority of the students favored legalizing cannabis for medical purposes. These three results contrast markedly from student attitudes described by Burke and Marx in a study conducted more than 40 years ago. In that study, only a small percentage of pharmacy students (16\%) supported the use of medical marijuana [32].

\section{CONCLUSION}

Most pharmacy students supported medical cannabis legalization in our study. From the results, it can also be concluded that strict legal regulations concerning control of selling cannabis and its derivates as well as clear guidelines for their use should be implemented. Further education of the pharmacist about therapeutical effect of cannabis is necessary. Therefore, pharmacy schools need to evaluate the adequacy of medical marijuana education in their courses and consider revising curriculum accordingly.

\section{ACKNOWLEDGEMENTS}

This work was supported by the Ministry of Science and Technological Development, Republic of Serbia (project No. 41012) and by the Provincial Secretariat for Science and Technological Development, Autonomous Province of Vojvodina (project No.114-451-2178/201603). 


\section{REFERENCES}

1. Zuardi AW. History of cannabis as a medicine: a review. Rev Bras Psiquiatr. 2006; 28 (2): 153-7.

2. Guy G, Whittle BA, Robson PJ. Medical Uses of Cannabis and Cannabinoids. London: Pharmaceutical Press. 2004.

3. United Nations Office on Drugs and Crime. World Drug Report 2015 (United Nations publication, Sales No. E.15.XI.6)

4. Aggarwal SK, Carter GT, Sullivan MD, ZumBrunnen C, Morrill R, Mayer JD. Medicinal use of cannabis in the United States: historical perspectives, current trends, and future directions. J Opioid Manag. 2009; 5(3):153-168.

5. Ben Amar M. Cannabinoids in medicine: a review of their therapeutic potential. J Ethnopharmacol. 2006; 105(1-2):1-25.

6. Haney M, Gunderson EW, Rabkin J, et al. Dronabinol and marijuana in HIV-positive marijuana smokers. Caloric intake, mood, and sleep. J Acquir Immune DeficSyndr. 2007; 45(5):545-54.

7. Wilsey B, Marcotte T, Tsodikov A, et al. A randomized, placebo controlled, crossover trial of cannabis cigarettes in neuropathic pain. J Pain. 2008; 9(6):506-21.

8. Zhan GL, Camras CB, Palmberg PF, Toris CB. Effects of marijuana on aqueous humor dynamics in a glaucoma patient. J Glaucoma. 2005; 14(2):175-7.

9. United Patients Group. Ways to consume medical cannabis. http://www.unitedpatientsgroup.com/ resources/methods-of-consumption (accessed October 23, 2017).

10. Hall W, Solowij N, Lemon J. The health and psychological consequences of cannabis use. National Drug Strategy Monograph Series No 25. Canberra: Australian Government Publishing Service, 1994.

11. Tomida I, Azuara-Blanco A, House H, Flint M, Pertwee RG, Robson PJ. Effect of sublingual application of cannabinoids on intraocular pressure: a pilot study. J Glaucoma 2006; 15: 349-53.

12. Berenji J, Martinov M.: Hemp in Yugoslavia: past, present and future. Proceedings of the " 2 . BiorohstoffHanf” Frankfurt am Main 1997; 91-101

13. Criminal Code of the Kingdom of Serbs, Croats and Slovenes. Belgrade: Državnaštamparija. 1929. pp. 70-71.

14. European Monitoring Centre for Drugs and Drug Addiction (2017), Cannabis legislation in Europe: an overview, Publications Office of the European Union, Luxembourg.

15. Bifulco M, Pisanti S. Medicinal use of cannabis in Europe. EMBO reports. 2015; 16(2):130-2.

16. Neziri H. use of marijuana for therapeutic pur- poses - pro i contra. Diploma Thesis, Zagreb, 2015.

17. Moeller KE, Woods B. Pharmacy Students' Knowledge and Attitudes Regarding Medical Marijuana. American Journal of Pharmaceutical Education. 2015; 79(6):85.

18. Petro DJ. Marihuana as a therapeutic agent for muscle spasm or spasticity. Psychosomatics 1980; 21: 81-5.

19. Jain AK, Ryan JR, McMahon FG, Smith G. Evaluation of intramuscular levonantradol and placebo in acute postoperative pain. Journal of Clinical Pharmacology 1981; 21:320S-6S.

20. Hollister LE. Health aspects of cannabis. Pharmacological Reviews 1986; 38: 1-20.

21. Johansson R, Kikku P, Groenroos M. A double blind controlled trial of Nabilonevsprochlorperazine for refractory emesis induced by cancer chemotherapy. Cancer Treatment Review 1982; 9 (Suppl. B): 25-33.

22. Chesher GB, Jackson DM. The quasi morphine withdrawal syndrome: effect of cannabinol, cannabidiol and terahydrocannabinol. Pharmacology Biochemistry and Behaviour 1985; 23: 13-15.

23. Beal JA, Olson R, Laubenstein L, Morales JO, Bellman P, Yangco B. Dronabinol as treatment for anorexia associated with weight loss in patients with AIDS. Journal of Pain and Symptom Management 1995; 10: 89-97.

24. Cunha JM, Carlini EA, Pereira E. Chronic administration of cannabidiol to healthy volunteers and epileptic patients. Pharmacology 1980; 21: 175-85.

25. Merritt JC, Crawford WJ, Alexander PC. Effect of marihuana on intraocular and blood pressure in glaucoma. Ophthalmology 1980; 87: 222-8.

26. Mallat AM, Roberson J, Broch-Utne JG. Preoperative marijuana inhalation and airway concern. Canadian Journal of Anesthesia 1996; 43: 691-3.

27. Pertwee RG. Tolerance to and dependence on psychotropic cannabinoids. In: Pratt JA, ed. The Biological Bases of Drug Tolerance and Dependence. London: Academic Press, 1991; 231-63.

28. United Nations Office on Drugs and Crime, The Illicit Drug Trade through South-Eastern Europe 2014, United Nations publication, March 2014

29. Balkan Insight. 2015. Croatia legalizes marijuana for medical use. http://www. balkaninsight. com/en/article/croatia-firstbalkan-county-to-legalize-medical-marijuana-10-15-2015-1 (accessed October 23, 2015).

30. European Monitoring Centre for Drugs and Drug Addiction (2017), Cannabis legislation in Europe: an overview, Publications Office of the European Union, Luxembourg

31. Vujcic I, Pavlovic A, Dubljanin E, Maksimovic J, 
Nikolic A, Sipetic-Grujicic S. Attitudes Toward Medical Cannabis Legalization Among Serbian Medical Students. Subst Use Misuse. 2017;52(9):122531. doi: 10.1080/10826084.2017.1302959.

32. Burke WM, Marx MB. Attitudes of professional students toward legal control of psychoactive substances. HSMHA Health Rep.1971; 86(8):725-32. 


\title{
Znanje i stavovi studenata farmacije u vezi sa upotrebom kanabisa u medicinske svrhe
}

\author{
Marina S. Stojanović ${ }^{1}$, Ana D. Tomas ${ }^{1}$, Milica M. Paut-Kusturica ${ }^{1}$, \\ Aleksandar L. Rašković ${ }^{1}$, Milan B. Ubavić́ ${ }^{2}$ Zdenko S. Tomić ${ }^{1}$, Ana J. Sabo ${ }^{1}$, \\ Olga J. Horvat ${ }^{1}$ \\ ${ }^{1}$ Katedra za farmakologiju, toksikologiju i kliničku farmakologiju, Medicinski fakultet Novi Sad, \\ Univerzitet u Novom Sadu, Novi Sad, Srbija \\ ${ }^{2}$ Zavod za laboratorijsku dijagnostiku, Medlab, Novi Sad, Srbija
}

\section{KRATAK SADRŽAJ}

Uvod: Kako je poslednjih godina u Srbiji sve veće interesovanje javnosti za legalizacijom kanabisa u terapijske svrhe, farmaceuti često bivaju konsultovani o bezbednosti, efikasnosti kanabisa i njegovih pripravaka. Zbog toga je cilj naše studije bio odrediti znanje i stavove studenata farmacije o upotrebi kanabisa i njegovih pripravaka u terapijske svrhe u Srbiji kako bi se uvidelo da li je potrebno poboljšati edukaciju o toj temi.

Metodologija: Istraživanje je sprovedeno na slučajnom uzorku od 80 studenata završne godine studije farmacije Medicinskog fakulteta u Novom Sadu. Studenti su bili zamoljeni da popune anonimni upitnik koji bi pokazao njihovo znanje i stavove o upotrebi kanabisa i njegovih pripravaka u terapijsk svrhe. Svi ispitanici su pre popunjavanja upitnika dobili informacije o ispitivanju, pročitali informacije za ispitanike i potpisali informisani pristanak. Istraživanje je sprovedeno u periodu od 1.8.2017 do 15.8.2017. i odobreno je od strane Komisije za etičnost kliničkih ispitivanjana, Medicinskog fakulteta u Novom Sadu. Upitnik se sastojao od tri grupe izjava sa kojima su studenti bili zamoljeni da označe stepen slaganja, ako jesu se odnosile na znanje studenata o upotrebi kanabisa i njegovih pripravaka u terapijske svrhe, potencijalnim negativnim efektima, izdavanju u apoteci i legalizaciji kanabisa i njegovih pripravak u terapijske svrhe.

Rezultati: lako se 91 , 2\% ispitanika složilo da kanabis i njegovi pripravci potencijalno mogu imati terapijski efekat, znatno niži procenat ispitanika $(51,3 \%)$ bio je upoznat sa mogućim terapijskim dejstvima kanabisa. Isti procenat ispitanika edukovao se o tome, osim na fakultetu, i na dodatnim edukacijama. Oko 30\% smatralo je da upotreba kanabisa i njegovih pripravaka u terapijske svrhe potencijalno može izazvati njihovu zloupotrebu, a sličan procenat ispitanika $(33,8 \%)$ smatrao je da izdavanje kanabisa i njegovih pripravaka u apoteci može izložiti farmaceuta određenim opasnostima kao sto su insistiranje na bezreceptnom izdavanju ili pljačka. Oko 90 \% ispitanika složilo se da su neophodne jasne smernice za upotrebu kanabisa i njegovih pripravaka u terapijske svrhe, a 76, 3\% ispitanika smatralo je da je za njihovo izdavanje neophodan lekarski recept. Većina ispitanika (75\%) složilo se da bi, na osnovu iskustava drugih država, upotreba kanabisa u medicinske svrhe trebala biti odobrena i u Srbiji.

Zaključak: Većina studenata farmacije je podržala upotebu kanabisa u terapijske svrhe, ali smatrajući da bi to trebalo biti praćeno striktnim zakonskim regulativama i jasno određenim smernicama. Neophodna je potpunija edukacija studenata farmacije o terapijskim efektima kanabisa.

Ključne reči: kanabis, stav, legalizacija, edukacija

Received: November 29, 2017

Accepted: December 11, 2017 